Review article

UDC 338.48(497.11 Zlatibor)

Received: 12. February 2020;

Received in revised form: 19. February 2020;

doi: $10.5937 /$ zrgfub2068117V

Accepted: 22. February 2020;

Available online: 25. February 2020

\title{
RESIDENTIAL TOURISM AS A NUCLEUS OF MASSIVE TOURISM - ZLATIBOR
}

\author{
Dunja Vuković*1 \\ *University of Belgrade - Faculty of Geography, Belgrade
}

\begin{abstract}
The affirmation of Zlatibor as a tourist destination dates back to ancient times, so Zlatibor can be proud of its tradition of over 150 years. The turning point in the development of Zlatibor tourism is the visit of the Serbian sovereign Alexander I Obrenović. In 1893, two important tourist settlements were located on the mountain and residential objects were built. Therefore, the previously mentioned year is considered to be the beginning of organized tourism on Zlatibor.

The second turning point in the development was the construction of a modern road that connected Užice with Kraljeva Voda, at the time when the interest of tourists exceeded the accommodation capacities. At the beginning of the 1930s due to the numerous values of Zlatibor, its favorable position and good transport connections with all parts of Serbia and neighboring countries, tourism on Zlatibor started to develop.

The Zlatibor Resort, on the mountain of the same name, annually receives over one million overnight stays, mainly by domestic tourists, making it one of the most visited tourist destinations in the Republic of Serbia. The types of tourist services are sports, recreational, health and congress tourism, and in recent years, tourist offers for children and youth have become more important.

Accordingly, Zlatibor, as a tourist center, has no significant competition in Serbia or in the region. With further development and investment in tourism, Zlatibor will carry for a long time the epithet of the most visited and most attractive tourist destination of Serbia, despite its obvious shortcomings.
\end{abstract}

Key words: Zlatibor, tourism, natural values, accommodation capacities.

\footnotetext{
${ }^{1}$ Corresponding author: D. Vuković, University of Belgrade- Faculty of Geography, Studentski trg 3/III, Belgrade; email: dunjav92@gmail.com
} 


\section{Introduction}

"Nest of the Gods for Vacation", Milić od Mačve (1986); this is how our distinguished painter describes Zlatibor. Everything in the late 1980s - the natural beauty, the famous "rose of the winds", the healing effect and the benefits that mountain had to offer, indicated that Zlatibor would become one of the largest tourist centers in Serbia.

The development of tourism in Zlatibor is a process during which nature and people, each in their own way, built and left a wonderful tourist legacy for future generations. The tourism development has shown that nature has always been faster, more generous and far-sighted, while people have always lagged behind, struggling to reach the incredible beauty of nature, to master it and make it accessible to the widest range of visitors. Thus, Zlatibor finally received all the contours of a modern tourist center (Đenić, 2003).

\section{Natural characteristics of Zlatibor}

Zlatibor is located on the border of Serbia, Montenegro and Bosnia and Herzegovina. It is an integral part of the Starovlaška visija (highland) and at the same time makes the transition to the lower Dinara mountain. It is, in fact, a large, flattened serpentine plateau, with an average altitude of 1000 meters, intersected by numerous rivers, streams, and watercourses, while the mountainous heights, with a domed shape, are located almost only along the edges. The highest peaks are Tornik (1496 m), Brijač on Murtenica (1462 m), Bandera on Čigota (1438 m) and Čigota (1422 m). Altitude is undoubtedly a recreational and therapeutic factor. One of the most famous features of Zlatibor is Stopića pećina (cave). It is about $2 \mathrm{~km}$ long, with the height of the vault in some places reaching up to $50 \mathrm{~m}$. It is full of stalactites and stalagmites, tubs up to $10 \mathrm{~m}$ large and nice big hollows. Nature itself builds the aesthetics of the landscape, and in the area of Zlatibor was extremely generous.

The climate of the wider area of Zlatibor is considered to be mountainous, temperate - continental (subalpine). However, it is differentiated due to different terrain elevations and different orthographic exposure to air currents. At high altitudes above this range, air masses collide and permeate. In addition to the high presence of ozone and oxygen, climatic suitability is reflected in moderately cold winters (the lowest mean temperature in January is $-4.8^{\circ} \mathrm{C}$ ) and mild summers with no tropical heat (the highest mean temperature in August is $24^{\circ} \mathrm{C}$ ). The air is moderately humid (at the border moderately dry) throughout the year, as its average annual relative humidity is $75 \%$, with small annual fluctuations of up to $15 \%$. 
Sunbathing is 2052.9 hours, while the number of cloudy days is 68 in the year. The maximum duration of sunbathing is in July (277.3 hours) and August (269.9 hours), when the cloudiness is lowest and when the days are the longest. The lowest sunshine is in December (76.6 hours) and January (91.6 hours), which is caused by significantly higher clouds and shorter days (Meteorološki godišnjak, 1990-2018). Annual precipitation is $890 \mathrm{~mm}$, with maximums in May (104 mm) and June $(91 \mathrm{~mm})$ and minimum in February $(56 \mathrm{~mm})$ and January $(57 \mathrm{~mm})$. In winter, precipitation is excreted in the form of snow. The average annual retention of the snow cover is 95 days and the average thickness is $56 \mathrm{~cm}$ (Stanković, Ćirković, 2002).

Air flow is expressed, but strong and stormy winds are a rare occurrence. The most common winds are southwest, south and northeast, and the rainiest ones are west and southeast. The strongest winds are south (average $3.2 \mathrm{~m} / \mathrm{s}$ ) and southwest $(2.6 \mathrm{~m} / \mathrm{s})$. Although the most common wind is southwestern and it rains in early summer and fall, rainfall is relatively small, about $1028.8 \mathrm{~mm}$ on average per year (Meteorološki godišnjak, 1990-2018).

Many experts have written about the healing properties of the climate of Zlatibor: a team of the Red Cross European specialists after the end of World War I; before the Second World War in "Pravda" and "Rasvit", wrote Dragoslav Zeka Smiljanić from Ljubiš; After World War II, numerous professional publications were published, including the "Physician's Handbook" in 1955. Scientific research of Zlatibor was published in 1963 by the Balneo-climatological Institute of the Republic of Serbia. Based on the above reports it has been concluded that Zlatibor is a therapeutic area for the following diseases: anemia, lung diseases of any etymology; neurovegetative disorders as well as conditions of reconvalescence after acute infectious diseases and after surgical interventions (Đenić, 1972).

The hydrological system of Zlatibor is characterized by its richness of waters, but not by its dense river network. All waters belong to the Black Sea basin. On the southern rim of the mountain flows the mighty Uvac river, with its wedged meanders - a true masterpiece of nature. Crni Rzav river emerges beneath the northwestern slopes of Murtenica. It is a typical Zlatibor river, which springs and mostly flows through its territory. The Veliki Rzav river runs along the eastern border of Zlatibor. It is one of the cleanest watercourses in Serbia. The northern parts of Zlatibor, due to the geological composition of the soil, are significantly poorer in water. Except the Sušica river, whose water disappears in the limestone during summer, there are no major rivers in this area (Đenić, 2003).

There are numerous water sources with cold mountain water on Zlatibor, some of them are the best in Serbia. The healthiest and coldest are the Hajdučka česma and Hajdučica in Murtenica, Zaugline under the Čigota peak and Jovanova voda in Alin potok. Near the village of Rožanstvo there is a source 
of healing water, spa Vapa. Water springs from great depths with its constant temperature of 17 degrees. In the valley of the river Ribnica there is a source of mineral water and several source fields. The results of an analysis conducted by the Institute of Chemistry, Technology and Metallurgy in Belgrade showed a $\mathrm{pH}$ factor of 11.20, which is unusually high. It is interesting that all sources have the same therapeutic properties - treating eye and skin diseases (Đenić, 2003).

Zlatibor has no natural lakes. There are two artificially created lakes. The first one was built in 1947 and then became one of the sights of the tourist center of Zlatibor. The second one, Lake of Ribnica, was created for the purposes of water supply in the late 1960s. By its appearance, it completely blended into the landscape of Zlatibor (Đenić, 2003).

The climate is well deserved for the lush vegetation of Zlatibor. Scientific research has shown that 440 different species of plants grow on the mountain. Three meadow types are represented: suvati - dry meadows, zakosi - slopes and luke - grasslands. About 120 species of plants grow on dry meadows, much more on the slopes where they are spared from destruction during grazing. The water is constantly soaking the plants on harbor meadows. It is important to point out that thirty species of Mediterranean grass grow in the fields of Zlatibor. Of the forest plantations, conifers dominate, while deciduous trees grow at smaller heights (Đenić, 2003). The rare forests of Zlatibor do not obscure the ultraviolet rays, as is the case in our forested mountains. Therefore, the physiological effect of ultraviolet radiation and its therapeutic effect are greater here than on mountains covered with dense forest (Ršumović, Milojević, Lazarević, 1991). There are also rarities such as golden pine (by which Zlatibor was named - Pinus Silvestris Variegata Zlatiborica), Pančićeva omorika and munika. Wild animals that constantly inhabit this area or occasionally appear make a rich fauna of the mountain. They can be hunted depending on the Hunting Law and the annual hunting management plan (Đenić, 2003).

\section{The beginnings of tourism development - residential tourism}

Zlatibor's affirmation as a tourist destination dates back to ancient times, with a tradition of over 150 years.

The beginning of residential tourism in Zlatibor (the construction of the first vacation homes) is considered to be the visit of Nikola Selak. This wealthy member of the Sarajevo aristocracy built a hut in Vodice in 1750. Today Vodice is a beautiful weekend village along the Crni Rzav river coast. Historical records show that Nikola Selak spent the next seven years in his hut resting his body and soul in the beauties of Tornik, Čavlovac, Murtenica and Crni Rzav. It took a whole century for the Serb princes, kings and other members of the Serbian 
aristocracy to follow his example, and even more time for the ordinary citizens of Serbia (Đenić, 2003).

During the Turkish rule, the Zlatibor lands and pastures were in the possession of the rich Turkish gentry which lived in Užice, Priboj and Nova Varoš and other wealthy Turks who built the first wooden structures and spent summers with their families there.

After the liberation of Serbia, the mountain changes its clientele, so the members of the young Serbian bourgeoisie vacationed there. There are reports that Prince Miloš Obrenović also visited Zlatibor and his friend, Serdar Jovan Mićić, who had a summer house on Kulaševac, where the famous Kraljeva voda is today. Prince Miloš probably did not come to Zlatibor only for the vacation and health benefits that Zlatibor offers, but also to visit areas where during the First Serbian Uprising he was the commander of the rebel forces.

At the turn of the 19th to the 20th century, vacationing at Zlatibor was a privilege for wealthy Užice's traders and their families. In addition to the shepherds' huts, rich people also made log cabins that housed their families during the summer. Staying at Zlatibor was considered a luxury and a fashion.

Another group of guests were the people suffering from vicious, contagious and difficult to cure-tuberculosis. Zlatibor was a lifeline for many, because of the clean air, complete peace, healing fragrant meadows and pine forests, cold and clean mountain water and good food. The mountain healed many, and extended life for many. However, people were faced with the problem of accommodation. There was no house or building on Zlatibor itself, where one could spend the night or eat something, except in Čajetina, where accommodation could be found in the houses of the villagers. Therefore, at the end of the 19th century, a systematic campaign of the press, various societies and prominent individuals began to build catering and tourist facilities in Zlatibor, and to start creating a modern health and tourist center.

The turning point in the development of Zlatibor tourism was 1893, when very important Serbian politicians of that time visited Zlatibor; especially important was Serbian sovereign Aleksandar I Obrenović. That summer, two of the most important tourist resorts were located and the first facilities were built, which was reason enough to take 1893 as the beginning of organized tourism in Zlatibor.

During his visit, the king promised to build a fountain at the source of Kulaševac, which was later built. The fountain still has the inscription: THE KING ALEXANDER I, August 20, 1893.

A modern sanatorium was to be built on Kraljeva voda, which was prevented by a series of unexpected political events, first by the Majski prevrat, and a few years later by the First Balkan War. On the eve of World War I, a modern 
and luxurious hotel called "Kraljeva voda", an annex of Čigota and a bakery, was built on Kraljeva voda. The mentioned tourist complex had dining room, a large terrace and a total of 29 beds. The hotel hosted guests for a short time, as World War I soon broke out (Đenić, 2003).

As long as the war consequences were felt and there was a bad road connection, poor accommodation facilities were enough for tourist needs. The second turning point in the development was the construction of modern road communication Užice-Kraljeva Voda, at the time when the interest of tourists exceeded the accommodation capacities of the hotel and villa "Čigota". For several years, the gendarmerie station building was also used to house guests. The growing interest in this Serbian mountain has stimulated the construction of new accommodation facilities. During 1929, the Villa "Belgrade" was built and the accommodation capacity was increased to a total of 65 beds.

Tourist offer has been seasonal in the first ten years. All accommodation facilities were leased exclusively from May 1st to September 30th. It is known that engineer Sekula Knežević Ćaldović built a restaurant named "Health". First, it was the "Paris" inn, and then the "Switzerland" restaurant, where six wooden pavilions were built in the first phase, and another five in the second, so that guests could use the full board.

During this period, only one resort, the Disability Home, was built, thanks to Užice lawyer Veljko Kremić. The Disability Home was located between Kraljeva Voda and Palisad. It was a facility with a kitchen, a dining room, and twenty rooms with 60 beds. This resort served as a recovery and healing center for the Serbian survivors who had consequences of the wounds sustained in the horrors of World War I.

In the early 1930s, the growth of both stationary and picnic tourism began. The report of the Zlatibor district shows that 500 guests were used the tourist services in 1932, then 504 domestic and 26 foreign tourists in 1937, what made a total of 2575 nights. The number of guests increased in the coming period and the record was reached in 1939, when 1960 tourists were in all tourist facilities, almost four times more than two years earlier. These figures do not include users near 60 villas in Kraljeva Voda and Palisad (Đenić, 2003).

\section{Tourist values of Zlatibor}

Good geographical position, good traffic connections with all parts of Serbia and neighboring countries make it easy to reach Zlatibor. The main routes are the Belgrade-Montenegro highway, as well as the Belgrade-Bar railway. The majority of tourists, besides the Serbian tourists, are guests from Montenegro 
and Bosnia and Herzegovina, then also guests from countries from the territory of the former SFRJ, due to the relative proximity, cultural and linguistic similarities, as well as the inherited value of the Zlatibor brand. In the current circumstances, characterized by lack of highway (until the end of the corridor to the southern Adriatic) and a considerable distance from international airports, Zlatibor cannot count on the significant arrival of foreign tourists, although tourists from Russia, China and other countries appear sporadically.

The Belgrade-Southern Adriatic and Belgrade-Požega highways can make a significant contribution to the competitiveness of the Zlatibor region, due to its fast road connection with Belgrade, as the largest market in the region, and thus with the International airport "Nikola Tesla". On the other hand, Zlatibor is still a significant vacation destination for travelers to the Adriatic. The tourist potential of Zlatibor includes the natural beauties of the area (Stopića pećina, RibnicaSki Center "Tornik", Staro selo Sirogojno -opan-air museum, Vodice, Tripkova, Mačkat, Kriva Reka, Gostilje - waterfall, Skakavac - waterfall u Semegnjevu, etc.), traditional cuisine, healthy food, old crafts, typical rural buildings built of natural materials (wood, stone, brick) in indigenous style of traditional architecture, contemporary hotels, restaurants, resorts and people ready to provide tourist services.

Today, Zlatibor is the most visited mountain destination in Serbia, with a high number of visits throughout the year. Due to its presence during all four seasons, Zlatibor has a very complex influence on the tourist market. In this way, as a tourist destination, it is clearly profiled towards the holiday segment of tourism and accordingly develops capacities. In addition, the participation of business guests increases, therefore the expansion of the so-called congress tourism allows the capacity to be filled during periods of low demand. The most important venues for conferences and congresses are the "Romanija" Convention Center, as well as the venues for these purposes within the hotels "Mona", "Palisad" and "Čigota Special Hospital". The aforementioned facilities record an increasing number of seminars, congresses, events and scientific meetings. In general, about 40 events are held annually in the Zlatibor District, many of them in Zlatibor. Accordingly, the highest number of nights in Zlatibor was realized in the category of hotels.

The main tourist products defined at Zlatibor are holiday, health and sportsrecreational tourism. In this context, in the "vacation" segment, during the summer season, Zlatibor presents a final destination and/or a place for a short break on the way to the southern Adriatic. During the summer period, Zlatibor competes with all other mountain centers in the region, but none of the mountain centers currently have a similar degree of development, so this competition is extremely limited. As a tourist destination, Zlatibor has no significant competition, as no other center on the Belgrade-South Adriatic corridor currently has 
nearly similar levels of the infrastructure development and accommodation offer (Zlatibor-Zlatar Strategic and Operational Tourism Marketing Plan, 2013).

In winter, Zlatibor directly competes with other mountain resorts that do not have significant ski sports, because, unlike them, it offers more tourist benefits, as well as skiing on Tornik. However, compared to destinations with significantly developed ski infrastructure (Kopaonik, Jahorina, Stara planina), Zlatibor is not a significant competitor in the skiing segment as a tourist product.

When it comes to health tourism, Zlatibor is branded as an air spa and is an important health tourism center in Serbia. Staying at Zlatibor helps in the treatment of certain diseases, as well as in rehabilitation, whether it is prevention or health treatment. Special Hospital for Thyroid and Metabolic Diseases "ČIGOTA" has a special health and tourism offer. Zlatibor also competes with health and spa tourism with other spa centers in the region. Due to significant devastation and lack of investments in spas in Serbia, Zlatibor is still far above its competitors.

When considering holiday and sport and recreational tourism, Zlatibor offers a developed product and it is more competitive with spa centers, other mountain destinations and some coastal areas in the southern Adriatic. In terms of sports and recreational facilities, Zlatibor is one of the most equipped destinations in the region. In addition to the above, it is important to mention the kind of tourism that is aimed at children and youth, which includes capacities intended for recreational teaching and school in nature. This implies a certain number of accommodation facilities for this purpose, as well as cultural, educational and sports facilities aimed at the youngest (Strategic and Operational Marketing Plan for Tourism in Zlatibor-Zlatar, 2013).

In addition to natural, anthropogenic values are of great importance for Zlatibor tourism. Some of them are of the local, regional or national character. These are values that enrich the tourist attraction of Zlatibor and can be archeological, monumental, ethnographic, ambient, artistic and manifestational. Of the archeological sites, the most numerous are the ruins. Today, in the territory of Zlatibor, there are four wooden churches from ancient times in the villages of Dobroselica, Jablanica, Draglica and Kućani; there are also churches in Sirogojno, Mačkat, Bela Reka, Čajetina and in the resort Zlatibor. The most important monasteries are Uvac, Dubrava and Rujno. The birthplace of Dimitrije Tucović in Gostilje and Sava Jovanović in Trnava are mostly visited by locals. Ethno Village Sirogojno - open-air museum "Staro selo" preserves the most beautiful specimens of Zlatibor houses and other objects that made up the rural household. Ethno villages are very popular, and tourists are happy to visit them and to organize various activities. Monuments and stećci (tombstones) have no major tourist significance (Đenić, 1972). The most important museums and galleries are the endowment of the painter Božidar Kovačević at Borova Glava, 
the "Vodenica" gallery, by painter Branko Tijanić and the "Trnava" gallery by Vladimir Mitrović (Đenić, 2009).

\section{Tourist - catering capacities and the development of mass tourism}

Tourism is the dominant activity of the local economy. The Zlatibor Tourist Center, on the mountain of the same name, annually receives over one million overnight stays, mostly by domestic tourists. The most common types of tourist services are sports-recreational, health and congress tourism, while in recent years, children's and youth tourism has also become more important (Strategic and operational marketing plan for tourism in Zlatibor-Zlatar, 2013).

Official data of the number of tourists and overnight stays date back to 1955. Over the next ten years, there has been a steady increase in the number of domestic tourists, with small variations. According to the data, at the end of the decade, the number of domestic tourists tripled, while the number of visits and overnights of foreign guests was negligible.

According to the Statistical Office of the Republic of Serbia, in the following decades, there has been a constant increase in both the number of tourists and the number of nights. We can say that the data in the tables, in addition to indicators relevant to tourism, also reflects social circumstances in the country. With the expansion of the economy in the country, there is an increase in the standard of living, which has enabled tourism-related activities for some part of the population. The share of foreign tourists among guests is still low, but it shows a certain shift.

Table 1. Number of tourists and number of nights per year

\begin{tabular}{|r|r|r|r|r|}
\hline \multirow{2}{*}{ Year } & \multicolumn{2}{|c|}{ Tourists } & \multicolumn{2}{c|}{ Nights } \\
\cline { 2 - 5 } & Domestic & \multicolumn{1}{c|}{ Foreign } & Domestic & \multicolumn{1}{c|}{ Foreign } \\
\hline 1990. & 109.979 & 994 & 640.893 & 2720 \\
\hline $\mathbf{1 9 9 1 .}$ & 84.235 & 600 & 523.165 & 2988 \\
\hline $\mathbf{1 9 9 2 .}$ & 98.435 & 286 & 578.373 & 1105 \\
\hline $\mathbf{1 9 9 3 .}$ & 60.106 & 250 & 353.875 & 1840 \\
\hline $\mathbf{1 9 9 4 .}$ & 59.237 & 783 & 370.979 & 2421 \\
\hline $\mathbf{1 9 9 5 .}$ & 75.196 & 837 & 456.077 & 3017 \\
\hline $\mathbf{1 9 9 6 .}$ & 70.048 & 932 & 423.709 & 3107 \\
\hline $\mathbf{1 9 9 7 .}$ & 69.939 & 1293 & 425.992 & 5029 \\
\hline $\mathbf{1 9 9 8 .}$ & 80.160 & 1415 & 490.953 & 2700 \\
\hline $\mathbf{1 9 9 9 .}$ & 50.500 & 800 & 30.2300 & \\
\hline
\end{tabular}

Source: Statistical Yearbooks of the Republic of Serbia from 1990 to 1999 


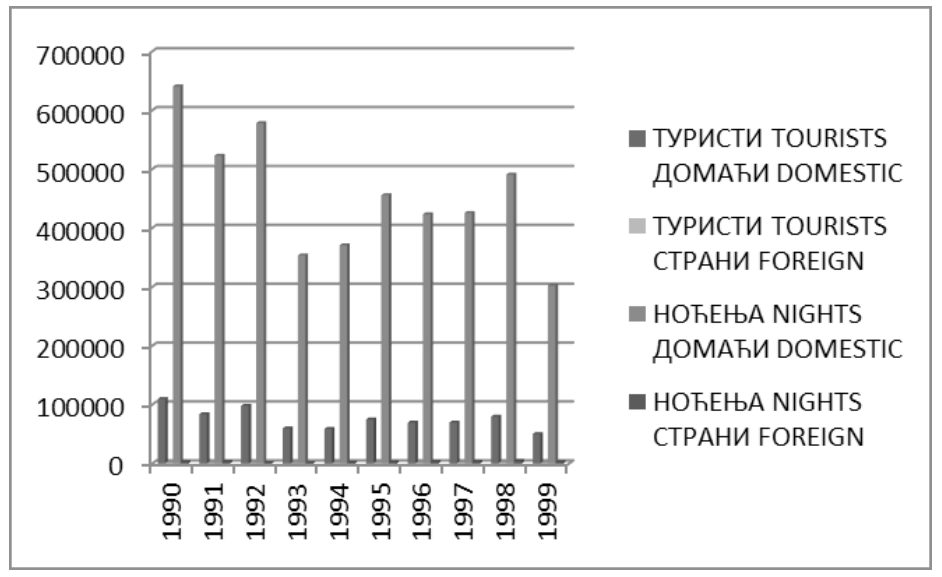

Chart 1. Overview of the number of tourists and overnight stays

In the early 1990s, or in the late 1980s, the country was facing an economic crisis affecting a large number of countries in the region. The war in these areas, which began in 1992, leads to a difficult situation in the country, which is reflected in the entire society, economy and even tourism. The data in the Table 1 clearly shows a drastic decline in both the number of domestic and foreign tourists until 1998, even though the war ended in 1995. It is evident that after the war, general conditions were not favorable to tourism. The data in tables then shows a slight increase in the number of domestic tourists in 1998, but also a drastic decline during the 1999 bombing. The number of foreign tourists is still negligible compared to the number of domestic tourists.

Table 2. Number of tourists and number of nights per year

\begin{tabular}{|r|r|r|r|r|r|}
\hline \multirow{2}{*}{ Year } & \multicolumn{2}{|c|}{ Arrivals } & \multicolumn{2}{c|}{ Nights } & \multirow{2}{*}{ Beds } \\
\cline { 2 - 5 } & Total & Foreign & \multicolumn{1}{c|}{ Total } & \multicolumn{1}{c|}{ Foreign } & \\
\hline 2000. & 73.616 & 2906 & 444.609 & 11.861 & $/$ \\
\hline $\mathbf{2 0 0 1 .}$ & 78.320 & 3573 & 455.418 & 13.821 & $/$ \\
\hline $\mathbf{2 0 0 2 .}$ & 73.122 & 4137 & 387.649 & 15.037 & 3812 \\
\hline $\mathbf{2 0 0 3 .}$ & 71.000 & 5000 & 331.000 & 16.000 & 3834 \\
\hline $\mathbf{2 0 0 4 .}$ & 83.000 & 6000 & 344.000 & 18.000 & 3669 \\
\hline $\mathbf{2 0 0 5 .}$ & 81.000 & 7000 & 346.000 & 21.000 & 3906 \\
\hline $\mathbf{2 0 0 6 .}$ & 88.000 & 9000 & 377.000 & 28.000 & 3934 \\
\hline $\mathbf{2 0 0 7 .}$ & 102.000 & 12.000 & 434.000 & 39.000 & 3917 \\
\hline $\mathbf{2 0 0 8 .}$ & 104.000 & 14.000 & 436.000 & 46.000 & 3771 \\
\hline $\mathbf{2 0 0 9 .}$ & 93.093 & 13.284 & 388.977 & 43.625 & $/$ \\
\hline
\end{tabular}

Source: Statistical Yearbooks of the Republic of Serbia from 2000 to 2009 


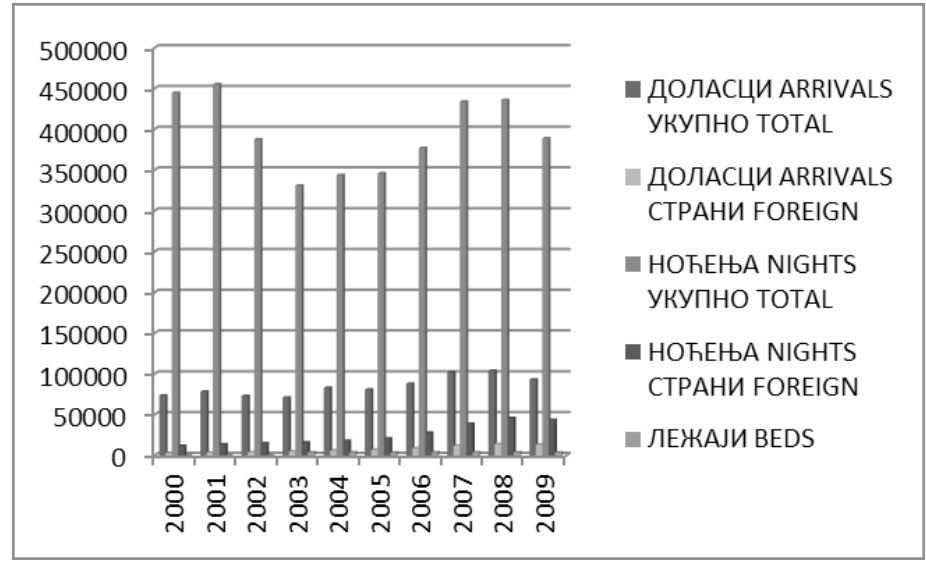

Chart 2: Overview of the number of tourists and overnight stays

Table 3. Number of tourists and number of nights per year

\begin{tabular}{|c|c|r|r|r|r|}
\hline \multirow{2}{*}{ Year } & \multicolumn{2}{|c|}{ Arrivals } & \multicolumn{2}{c|}{ Nights } & \multirow{2}{*}{ Beds } \\
\cline { 2 - 5 } & Total & Foreign & Total & \multicolumn{1}{c|}{ Foreign } & \\
\hline $\mathbf{2 0 1 0 .}$ & 104.824 & 16.785 & 404.224 & 51.641 & 4890 \\
\hline $\mathbf{2 0 1 1 .}$ & 118.248 & 19.650 & 483.316 & 65.046 & 4629 \\
\hline $\mathbf{2 0 1 2 .}$ & 110.934 & 18.185 & 463.363 & 61.660 & 5404 \\
\hline $\mathbf{2 0 1 3 .}$ & 114.976 & 21.118 & 455.759 & 67.415 & 4814 \\
\hline $\mathbf{2 0 1 4 .}$ & 111.963 & 24.292 & 426.831 & 78.578 & 5110 \\
\hline $\mathbf{2 0 1 5 .}$ & 148.372 & 33.879 & 556.751 & 100.590 & 5936 \\
\hline $\mathbf{2 0 1 6 .}$ & 178.620 & 42.501 & 651.798 & 120.014 & 6306 \\
\hline $\mathbf{2 0 1 7 .}$ & 195.172 & 46.724 & 713.607 & 132.188 & 6030 \\
\hline
\end{tabular}

Source: Statistical Yearbooks of the Republic of Serbia from 2010 to 2017

The beginning of the new millennium brings a kind of tourism boom, or an expansion of tourism and building of tourist capacities. The data in the table show a steady increase in the number of domestic guests and the number of nights, which can be explained by the economic growth and social circumstances. That growth has almost tripled from 2000-2017., increasing from about 70.000 guests to about 200.000 guests annually. The number of foreign tourists recorded an extreme increase, from about 3000 at the beginning of the measurement period to about 130.000 in 2017. 


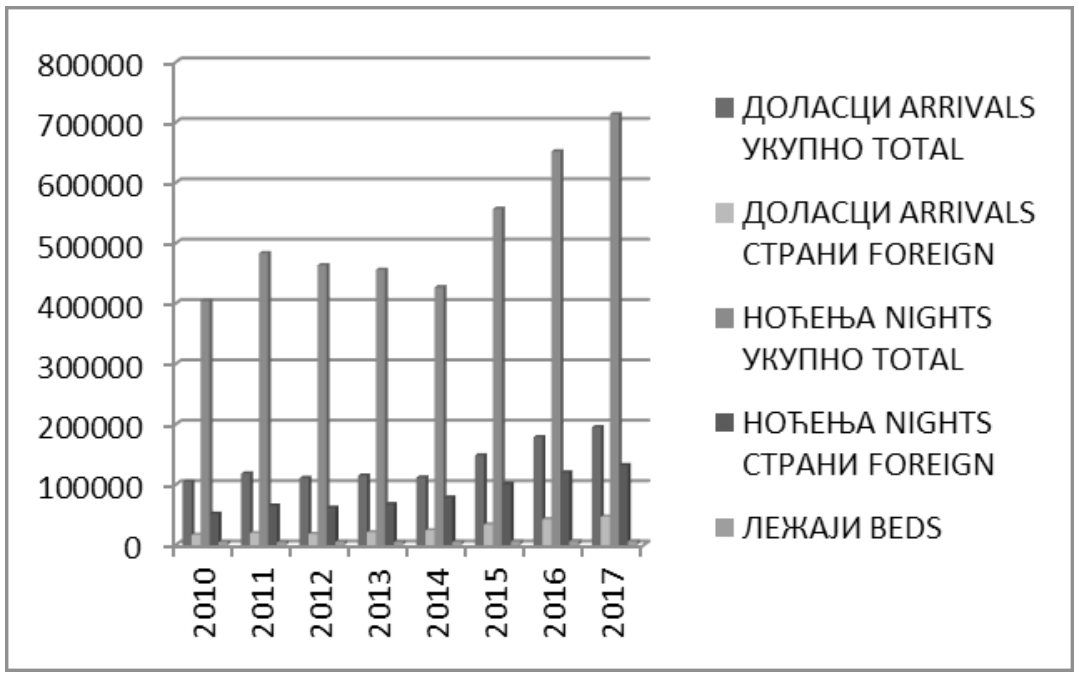

Chart 3. Overview of the number of tourists and overnight stays

\section{Conclusion}

The previous analyse, in my opinion, shows that the development of tourism in Zlatibor should have remained somewhere in the middle between residential and mass. The incredible natural values of this mountain have been partially destroyed by massive construction. This is especially true of the part of Zlatibor called Kraljeva Voda (the King's Water). The problem with mass tourism is negative impacts on the environment and survival of indigenous peoples, as well as on mountain flora and fauna. Mass tourism has led to an increase in drinking water consumption, an increase in wastewater and solid waste, to deforestation and the destruction of other vegetation and medicinal herbs, as well as to a complete change of the existing landscape of Zlatibor. Aesthetic degradation has been highlighted as a particularly significant problem because the principles of preserving the indigenous landscape and architectural style do not apply.

Lack of infrastructure, both road and electricity, water and sewerage are also a huge problem in Zlatibor resort. The existing infrastructure cannot support the expansion of mass construction, mostly unplanned, without the influence of urban and spatial planners.

Under the influence of tourism in the original territory, there has been an overload of facilities and people, as well as general degradation and change, in other words, the area loses its natural and indigenous qualities. In the last dec- 
ade of the 20th century, as well as at the beginning of the 21st century, the development of tourism in Zlatibor has largely gone the wrong direction. Zlatibor has become a type of settlement whose main function is tourism, without adequate planning development and control. Illegal construction and urban chaos have reduced the tourist attractiveness of Zlatibor. Excessive concentration of tourist and residential buildings has led to the loss of value of the area, and unfortunately to the pollution of land, water and air in the central settlement.

Environmental protection is a necessary segment in territorial planning, however, the lack of planning documents and the incompatibility of the environmental segment with other segments of the plan can significantly compromise its quality. Spatial plans often appear to be a group of several independent analytical studies, without the necessary synthetic component (Filipović, Obradović, 2005).

The positive effects of tourism on Zlatibor are represented almost as much as the negative ones, although it would be good if there were more. Tourism in Zlatibor has influenced the economy of this region, the employment of a huge number of workers in the construction, the tourism and hospitality sectors. Employment has reduced the departure of young people to major urban centers and abroad. The number of seasonal tourism workers is also significant. Mass tourism has undoubtedly contributed to the economic development of the municipality, which is one of the richest in Serbia today.

Zlatibor Tourism Organization today records an annual balance of around 300,000 visitors and about 1,300,000 overnight stays. The construction of a cable car lift will link the tourist center and the peak of Tornik. The Golden City at the interstation near Ribnica Lake is expected to increase the number of visitors to Zlatibor. The bus station is being moved from the center of the resort and a large parking lot is being built at the entrance to the tourist center in order to reduce the amount of noise, crowds and exhaust gases. Wastewater treatment plant is also under construction. The above will have a favorable environmental effect.

Accordingly, we can conclude that Zlatibor, as a tourist center has no significant competition in Serbia, nor in the region. With further development and investment in tourism, it is inevitable that the epithet of the most visited and attractive tourist destination of Serbia, despite the aforementioned disadvantages, Zlatibor will carry for a long time.

Acknowledgment: The work is the result of work on project 176017 funded by the Ministry of Education, Science and Technological Development of the Republic of Serbia. 


\section{References}

Đenić, M. (2003). Zlatiborski turizam kroz vekove. Zlatibor: Turistička organizacija "Zlatibor".

Republički hidrometeorološki zavod. (1990-2018). Meteorološki godišnjak. Beograd: Republički zavod za statistiku.

Stanković, S., Ćirković, S. (2002). Neke osobenosti prometa turista na Zlatiboru. Glasnik Srpskog geografskog društva, 82(1), 31-44.

Đenić, M. (1972). Zlatibor turistička panorama. Titovo Užice: „Dimitrije Tucović“.

Ršumović, R., Milojević, M., i Lazarević, M. (1991). Zlatibor geografska studija. Beograd: Srpska akademija nauka i umetnosti.

Regionalna razvojna agencija Zlatibor. (2013). Strateški i operationi marketing plan turizma destinacije Zlatibor-Zlatar. Užice: Regionalna razvojna agencija Zlatibor.

Đenić, S. (2009). Zlatibor kulturna i istorijska baština od praistorije do danas. Čajetina: Biblioteka „Ljubiša R. Đenić".

Republički zavod za statistiku. (1990-2017). Statistički godišnjaci Republike Srbije. Beograd: Republički zavod za statistiku.

Filipović, D., Obradović, D. (2005). Strateška procena uticaja u prostornom planiranju - instrument za utvrđivanje značaja planskih rešenja za zaštitu životne sredine i održivi razvoj, Glasnik Srpskog geografskog društva, 85(2), 119-126. 